\title{
Analisis Nilai Manfaat Ekonomi Program CSR dan PKBL PT. Bukit Asam (Tbk.)
}

\author{
Rabin Ibnu Zainal \\ Universitas Bina Darma \\ Email: rabin.zainal@binadarma.ac.id
}

\begin{abstract}
Corporate Social Responsibility (CSR) is a form of social responsibility from the business to also care about the conditions of the social environment around it. In this concept, businesses are not only required to realize their economic responsibilities in fulfilling the production of goods and services but are also asked to care about aspects of social and environmental responsibility affected by these production activities. PT. Bukit Asam (Tbk) (PTBA) as one of the companies engaged in coal mining in Muara Enim district, is also inseparable from the responsibilities that have been mandated in the form of related regulations and laws. PTBA as a BUMN is also mandated to implement the Partnership and Community Development Program (PKBL), which is also a form of CSR programs. In its implementation, if it is associated with the mandate of CSR and PKBL regulations, it is appropriate for the CSR-PKBL program not only to measure its business benefits, both in terms of the company's reputation, but also to continue to operate to the marketing aspects. However, CSR and PKBL must be able to provide economic benefits to the recipient community. For this reason, this study presents how the perspective of the community in seeing the CSR-PKBL program that has been conducted by PTBA to the community in Muara Enim Regency. The study was conducted in communities in 17 villages in 3 sub-districts identified as having received the CSR-PKBL program from 2014-2015. This study is useful for companies to provide a direction to the future CSR-PKBL program, and also to local governments to formulate policies related to the implementation of CSR-PKBL as mandated by law.
\end{abstract}

Keywords: CSR, PKBL, economics' benefit.

\begin{abstract}
Abstrak
Corporate Social Responsibility (CSR) adalah sebuah bentuk tanggung jawab sosial dari bisnis untuk juga peduli terhadap kondisi lingkungan sosial disekitarnya. Dalam konsep ini, bisnis bukan hanya dituntut untuk mewujudkan tanggung jawab ekonominya dalam pemenuhan produksi barang dan jasa, namun juga diminta untuk peduli terhadap aspek tanggung jawab sosial dan lingkungan yang terkena dampak dari aktivitas produksi tersebut. PT. Bukit Asam (tbk) (PTBA) sebagai salah satu perusahaan yang bergerak dalam tambang batubara di kabupaten Muara Enim, juga tidak terlepas dari tanggung jawab yang telah dimandatkan didalam bentuk regulasi dan perundang-undangan terkait. Ditambah lagi, PTBA sebagai BUMN juga diamanatkan untuk melaksanakan Program Kemitraan dan Bina Lingkungan (PKBL), yang juga merupakan bentuk program CSR. Dalam implementasinya, jika dikaitkan dengan amanat peraturan CSR dan PKBL, selayaknya program CSR-PKBL tidak hanya diukur manfaat bisnisnya, baik dari sisi reputasi perusahaan, kelanjutan beroperasi hingga kepada aspek pemasaran. Namun, CSR dan PKBL harus mampu memberikan nilai manfaat ekonomi kepada masyarakat penerima program. Untuk itulah, penelitian ini menyajikan bagaimana perspektif masyarakat dalam melihat program CSR-PKBL yang telah digulirkan oleh PTBA kepada masyarakat di Kabupaten Muara Enim. Studi dilakukan kepada masyarakat di 17 desa yang berada di 3 kecamatan yang diidentifikasi menerima program CSR-PKBL sejak tahun 2014-2015. Penelitian bermanfaat bagi perusahaan untuk memberikan arah terhadap program CSR-PKBL kedepan, dan juga kepada pemerintah daerah untuk merumuskan kebijakan-kebijakan terkait pelaksanaan CSR-PKBL seperti yang diamanatkan oleh undang-undang.
\end{abstract}

Kata kunci: CSR, PKBL, manfaat ekonomi.

\section{Pendahuluan}

Perusahaan ataupun organisasi bisnis tidak dipungkiri merupakan bagian dari komunitas masyarakat, dan karenanya itu juga memiliki tanggung jawab sosial atau sering juga disebut Corporate Social Responsibility (CSR). Paradigma ini telah mengubah orientasi 
dari tanggung jawab bisnis, dari yang sebelumnya hanya fokus untuk memenuhi kepentingan para pemegang saham (stockholder), menjadi semakin luas kepada tanggung jawab perusahaan terhadap masyarakat dan terutama kepada seluruh pemangku kepentingan (stakeholder) baik didalam (seperti karyawan dan keluarganya) maupun diluar perusahaan (supplier, konsumen, hingga masyarakat sekitar) (Carroll and Buchholtz, 2014). Terkait dengan tanggung jawab perusahaan terhadap komunitas masyarakat sekitar, negara Indonesia merupakan salah satu Negara yang pertama kali memandatkan CSR kepada perusahaan untuk menyalurkan proyek-proyek CSRnya hanya kepada masyarakat lokal sekitar wilayah operasinya (Waagstein, 2011). Walaupun regulasi yang dibuat penuh dengan kontroversi dan perdebatan, namun regulasi inilah yang dijadikan pedoman dalam pelaksanaan CSR di Indonesia.

Secara umum dalam literatur-literatur internasional, CSR dipahami sebagai komitmen perusahaan untuk berkontribusi dalam pembangunan ekonomi berkelanjutan, bekerja dengan para karyawan perusahaan, keluarga karyawan, komunitas lokal, dan komunitas secara keseluruhan dalam rangka meningkatkan kualitas kehidupan seperti yang didefinisikan oleh The World Business Council for Sustainable Development (Van Marrewijk, 2003). Berdasarkan definisi yang dipahami oleh literature internasion, terdapat beberapa stakeholder yang harus diperhatikan oleh perusahaan bisnis dalam melaksanakan CSR yaitu; karyawan perusahaan dan keluarganya, komunitas lokal dan komunitas secara keseuruhan (nasional dan global) dengan tujuan untuk meningkatkan kualitas kehidupan masyarakat melalui peningkatan kemampuan manusia sebagai individu untuk beradaptasi dengan keadaan sosial yang ada, menikmati, memanfaatkan, dan memelihara lingkungan hidup yang ada.

Pada kenyataannya, CSR telah dimandatkan melalui serangkaian regulasi di Indonesia. CSR walau masih sangat sedikit tapi sudah diatur secara tegas di Indonesia, yaitu dalam Undang-Undang Nomor 40 Tahun 2007 tentang Perseroan Terbatas, Undang-Undang Nomor 25 Tahun 2007 tentang Penanaman Modal, dan Peraturan Menteri Negara Badan Usaha Milik Negara Nomor Per-5/MBU/2007 tentang Program Kemitraan BUMN dengan Usaha Kecil dan Program Bina Lingkungan, khusus untuk perusahaanperusahaan BUMN. Namun, sejak regulasi CSR digulirkan tidak dapat dipungkiri bahwa CSR dari perusahaan bisnis di Indonesia selama ini hanya sebatas pemberian dukungan dana secara sukarela (voluntary) dan kedermawanan (philanthropy) sehingga kegiatan yang dilaksanakan kurang memberikan manfaat nyata bagi masyarakat (Anatan, 2010). Memang regulasi yang dibuat oleh pemerintah, lebih mengedepankan komunitas lokal sebagai objek dari proyek-proyek CSR perusahaan bisnis. Namun, bukan berarti bentukbentuk program hanya berupa proyek-proyek yang bersifat sukarela dan kedermawanan, yang tidak membangun kapasitas masyarakat untuk mandiri. Hal ini memunculkan rasa kekecewaan masyarakat dan pemerintah akan minimnya peran dunia usaha dalam kehidupan sosial dan adanya kecenderungan bahwa pelaksanaan CSR hanya sekedar sebagai bentuk untuk pemenuhan kewajiban perusahaan terhadap peraturan dan lebih bertujuan untuk membangun reputasi dan image perusahaan, bukan seperti yang diamanatkan dalam regulasi yaitu untuk mensejahterakan masyarakat lokal sekitar perusahaan (Irwanto and Prabowo, 2009). 
CSR tidak hanya menjadi isu perusahaan swasta tetapi juga menjadi bagian dari komitmen Badan Usaha Milik Negara (BUMN) yang sejalan dengan Good Coorporate Governance sebagai aplikasi dari Undang-Undang Nomor 40 Tahun 2007 tentang Perseroan Terbatas, Undang-Undang Nomor 25 Tahun 2007 tentang Penanaman Modal, Undang-Undang Nomor 19 Tahun 2003 tentang BUMN, Permen BUMN Nomor 5 Tahun 2007 tentang kemitraan Badan Usaha Milik Negara dengan usaha kecil dan Program Bina Lingkungan (Zainal, 2015).

PT. Bukit Asam (Persero) Tbk adalah Perusahaan Pertambangan yang dimiliki oleh Pemerintah Indonesia yang didirikan pada tahun 1950. Perusahaan Menjadi perusahaan publik di Bursa Efek Indonesia dengan kode "PTBA" pada 23 Desember 2002. PT Bukit Asam (Persero) Tbk mempunyai empat budaya perusahaan yakni kerja cerdas, kerja keras, kerja dengan benar dan bekerja dengan tulus. Awalnya, pertambangan batubara di Tanjung Enim ini diprakarsai oleh Pemerintah Kolonial Belanda pada tahun 1919 dengan mengoperasikan tambang batubara pertama menggunakan metode penambangan terbuka di Air Laya. Dengan menggunakan metode penambangan bawah tanah, operasi awal dimulai pada tahun 1923 berlangsung sampai tahun 1940, sementara produksi komersial dimulai pada tahun 1938.

Dalam kaitannya sebagai perusahaan yang terkait dengan pengelolaan Sumberdaya Alam diwajibakan untuk melaksanakan CSR, sedangkan status perusahaan sebagai BUMN juga terikat dengan kewajiban untuk melaksanakan PKBL. Untuk itu, studi ini akan melihat bagaiamana manfaat dari pelaksanakan kedua kewajiban tersebut, yaitu CSR dan PKBL kepada masyarakat. Penelitian bertujuan untuk mengidentifikasi manfaat ekonomi dari program CSR dan PKBL yang dilakukan oleh PT Bukit Asam.

\section{Literature Review}

Corporate Social Responsibility (CSR) merupakan salah satu wujud partisipasi dunia usaha dalam pembangunan berkelanjutan untuk mengembangkan program kepedulian perusahaan melalui penciptaan dan pemeliharaan keseimbangan antara mencetak keuntungan, fungsi-fungsi sosial, dan pemeliharaan lingkungan hidup. Dengan perkataan lain, CSR dikembangkan dengan koridor Tri Bottom Line yang mencakup profit, planet, dan people (Elkington, 2004).

Makin meningkatnya perhatian akan implementasi CSR menandai era kebangkitan masyarakat sehingga sudah seharusnya CSR tidak hanya menekankan pada aspek philantropy (dorongan kemanusiaan yang bersumber dari norma dan etika universal untuk menolong sesama dan memperjuangkan pemerataan sosial) maupun level strategi, melainkan harus makin diperluas pada tingkat kebijakan yang lebih makro dan riil (Gyves and O'Higgins, 2008).

Ambadar (2008) mengemukakan bahwa dalam perkembangannya telah terjadi pergeseran paradigma pelaksanaan tanggung jawab 61endid perusahaan yang meliputi corporate charity, corporate philantrophy, dan corporate citizenship. Tahap pertama, corporate charity merupakan dorongan amal berdasarkan motivasi keagamaan. Tahap kedua adalah corporate philantrophy, yakni dorongan kemanusiaan yang biasanya bersumber dari norma dan etika universal untuk menolong dan memperjuangkan pemerataan 61endid. 
Tahap ketiga adalah corporate citizenship, yaitu motivasi kewargaan demi mewujudkan keadilan berdasarkan prinsip keterlibatan.

CSR menjadi isu penting dalam menjamin kelangsungan hidup dunia usaha saat ini. Dunia usaha tidak akan 62end berkembang tanpa memperhatikan situasi dan kondisi lingkungan 62endid dimana perusahaan sehingga pelaksanaan CSR menjadi suatu keharusan bagi perusahaan dalam mendukung aktivitas bisnisnya, bukan hanya sekedar pelaksanaan tanggung jawab tetapi menjadi suatu kewajiban bagi dunia usaha. Implementasi CSR harus menjadi suatu bagian dalam peran bisnis dan termasuk dalam kebijakan bisnis perusahaan, sehingga dunia bisnis bukan hanya merupakan suatu organisasi yang berorientasi pada pencapaian laba maksimal tetapi juga menjadi suatu organisasi pembelajaran, dimana setiap individu yang terlibat didalamnya memiliki kesadaran 62endid dan rasa memiliki tidak hanya pada lingkungan organisasi saja melainkan juga pada lingkungan 62endid dimana perusahaan berada.

CSR sudah diatur secara tegas di Indonesia, yaitu dalam Undang-Undang Nomor 40 tahun 2007 tentang Perseroan Terbatas, Undang-Undang Nomor 25 Tahun 2007 tentang Penanaman Modal, dan Peraturan Menteri Negara Badan Usaha Milik Negara Nomor Per-5/MBU/2007 tentang Program Kemitraan BUMN dengan Usaha Kecil dan Program Bina Lingkungan, khusus untuk perusahaan-perusahaan BUMN.

Tanggung jawab 62endid perusahaan dicantumkan dalam Undang-Undang Nomor 40 Tahun 2007 tentang Perseroan Terbatas. Pasal 74 ayat (1) Undang-Undang ini menyatakan perseroan yang menjalankan kegiatan usahanya di bidang 62endidik berkaitan dengan sumber daya alam wajib melaksanakan tanggung jawab 62endid dan lingkungan. Ayat (2) pasal ini manyatakan kewajiban tersebut diperhitungkan sebagai biaya perseroan yang pelaksanaannya dilakukan dengan memperhatikan kepatutan dan kewajaran. Selanjutnya ayat (3) menyebutkan perseroan yang tidak melaksanakan kewajiban sebagaimana yang dimaksud ayat (1) dikenai sanksi sesuai dengan peraturan perundang-undangan yang terkait. Kemudian ayat (4) menyatakan ketentuan lebih lanjut mengenai tanggung jawab 62endid dan lingkungan diatur dengan Peraturan Pemerintah.

Menurut Undang-Undang Nomor 40 Tahun 2007 tentang Perseroan Terbatas pengertian CSR dalam Pasal 1 angka 3 menyebutkan tanggungjawab 62endid dan lingkungan adalah komitmen perseroan untuk berperan serta dalam pembangunan ekonomi berkelanjutan guna meningkatkan kualitas kehidupan dan lingkungan yang bermanfaat, baik bagi Perseroan sendiri, komunitas setempat, maupun masyarakat pada umumnya. UndangUndang Nomor 25 Tahun 2007 tentang Penanaman Modal, dalam penjelasannya pasal 15 huruf $b$ disebutkan tanggung jawab 62endid perusahaan adalah tanggung jawab yang melekat pada setiap perusahaan penanaman modal untuk tetap menciptakan hubungan yang serasi, seimbang, dan sesuai dengan lingkungan, nilai, norma, dan budaya masyarakat setempat. Tampak bahwa Undang-Undang Nomor 40 Tahun 2007 tentang Perseroan Terbatas mencoba memisahkan antara tanggung jawab 62endid dengan tanggung jawab lingkungan, yang mengarah pada CSR sebagai sebuah komitmen perusahaan terhadap pembangunan ekonomi berkelanjutan dalam upaya meningkatkan kualitas kehidupan dan lingkungan. 
Peraturan Menteri Negara Badan Usaha Milik Negara Nomor Per-5/MBU/2007 tentang Program Kemitraan BUMN dengan Usaha Kecil dan Program Bina Lingkungan, konsep CSR dapat dipahami dalam Pasal 2 bahwa menjadi kewajiban bagi BUMN baik Perum maupun Persero untuk melaksanakannya.

Pelaksanaan CSR seharusnya bukan hanya berdampak kepada perusahaan bisnis saja, namun juga harus menyentuh kepada manfaat yang diterima oleh masyarakat sebagai objek dari CSR tersebut. Analisis manfaat yang berkembang selama ini lebih menekankan manfaat CSR dari sisi bisnis. Seperti yang diungkapkan oleh Lenssen et. Al (2010) yang mengkategorikan manfaat CSR kepada bisnis kepada beberapa kategori seperti dibawah ini.

Gambar 1. Manfaat CSR bagi Bisnis

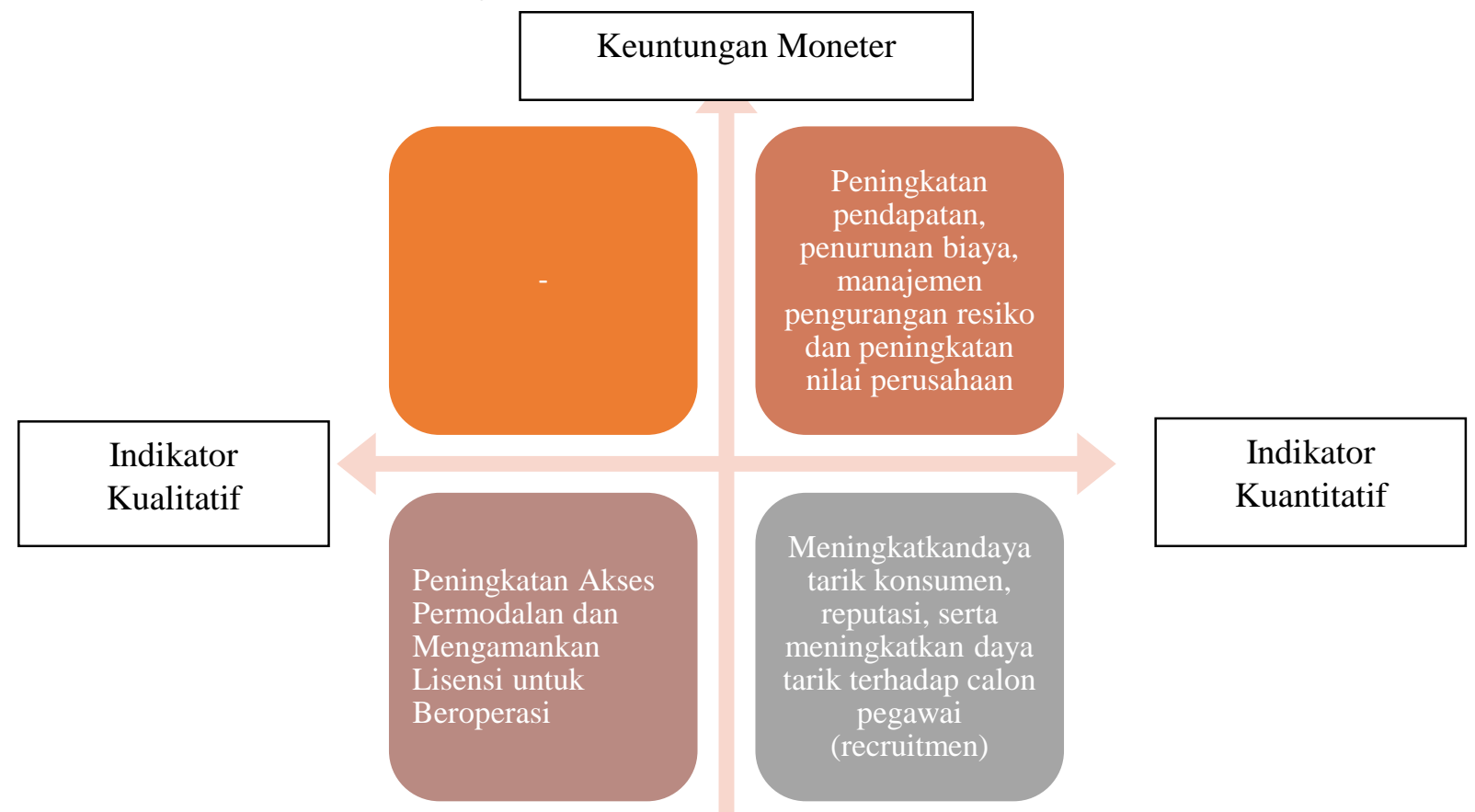

Keuntungan Non-Moneter

Sumber : (Lenssen et al., 2010)

Berdasarkan grafik diatas, manfaat CSR kepada bisnis dapat dikategorikan dalam empat area; 1)area non moneter dan indikator kualitatif yang menggambarkan manfaat CSR kepada bisnis terdiri dari peningkatan terhadap akses permodalan dan lisensi untuk beroperasi kepada bisnis, 2)area non meter dan indikator kuantitatif yang menggambarkan dampak manfaat kepada bisnis berupa peningkatan daya tarik kepada konsumen, peningkatan reputasi perusahaan dan meningkatkan rekrutmen pegawai, 3)area moneter dan indikator kuantitatif memperlihatkan manfaat CSR kepada bisnis 
berupa peningkatan pendapatan, penurunan biaya, manajemen resiko dan peningkatan nilai perusahaan.

Sedangkan dampak manfaat CSR kepada masyarakat terdiri dari tiga jenis kriteria pengukuran terhadap masyarakat. Adapun literatur-literatur yang meihat dampak manfaat CSR kepada masyarakat digambarkan dalam tabel berikut.

Tabel 1. Indikator Dampak CSR Terhadap Masyarakat

\section{Input Sosial Kriteria Proses Kriteria Benefit Sosial}

\begin{tabular}{|c|c|c|c|}
\hline $\begin{array}{l}\text { Indikator dari } \\
\text { penelitian dan } \\
\text { Praktek CSR }\end{array}$ & $\begin{array}{l}\text { Nilai dukungan } \\
\text { terhadap } \\
\text { masyarakat : jumlah } \\
\text { uang, waktu, } \\
\text { barang/ } \\
\text { perlengkapan }\end{array}$ & $\begin{array}{l}\text { Inklusi masyarakat } \\
\text { sebagai mitra, dialog } \\
\text { yang dibangun, dan } \\
\text { level inovasi bersama }\end{array}$ & $\begin{array}{l}\text { Peningkatan modal sosial, } \\
\text { dampak sosial masyarakat } \\
\text { (jumlah penerima } \\
\text { manfaat), dampak positif } \\
\text { terhadap individu } \\
\text { stakeholder, dampak } \\
\text { jangka panjang terhadap } \\
\text { masyarakat }\end{array}$ \\
\hline $\begin{array}{l}\text { Indikator } \\
\text { digunakan oleh } \\
\text { praktisi } \\
\text { pembangunan }\end{array}$ & - & $\begin{array}{l}\text { Kinerja donor, kinerja } \\
\text { penerima manfaat, } \\
\text { effisiensi dan } \\
\text { kesesuaian } \\
\text { penggunaan } \\
\text { sumberdaya }\end{array}$ & $\begin{array}{l}\text { Outcome (relevansi, } \\
\text { dampak pembangunan, } \\
\text { effisiensi), keberlanjutan, } \\
\text { dampak terhadap institusi } \\
\text { pembangunan, signifikansi } \\
\text { dalam konteks luas }\end{array}$ \\
\hline
\end{tabular}

Sumber : (Lenssen et al., 2010)

Untuk mengukur manfaat CSR kepada masyarakat terdapat tiga kriteria yang sering dipakai, baik dalam penelitian-penelitian literatur maupun praktisi pembangunan internasional. Terkait dengan survey ini, penelitian akan menggunakan indikator kriteria manfaat sosial yang digunakan dalam penelitian-penelitian CSR yang terdiri dari dua kriteria (1) Manfaat sosial, yang terdiri dari peningkatan modal sosial (kerjasama perusahaan dan masyarakat, tingkat kepercayaan masyarakat kepada perusahaan, dan pelibatan/ inklusi kelompok marjinal dalam program CSR; dan (2) Manfaat Ekonomi, yang terdiri dari berapa nilai dukungan terhadap komunitas (dalam bentuk jumlah uang, program), serta jumlah peningkatan pendapatan individu stakeholder akibat dari program CSR (pengurangan biaya transportasi, ekstensifikasi/ intensifikasi, diverisifikasi pedapatan, dll). Studi ini berada dalam ruang lingkup untuk penilaian manfaat ekonomi dari program CSR dan PKBL kepada masyarakat.

\section{Metodologi Penelitian}

Data yang dibutuhkan dalam penelitian ini adalah data primer dan data sekunder yang bersifat kualitatif dan kuantitatif. Data primer diperoleh dari masyarakat langsung yang dijadikan objek penelitian sedangkan data sekunder diperoleh dari perusahaan atau pemerintah berupa dokumen tentang kebijakan, rencana dan realisasi CSR. Data sekunder juga dapat diperoleh melalui buku, majalah, internet, surat kabar dan instansi-instansi yang relevan dengan penelitian ini. 
Pengumpulan data dilakukan dengan cara studi 65endidikan, pengisian kuisioner dan wawancara, serta pengumpulan data-data 65endidika yang turut membantu dalam penelitian. Pengumpulan data primer dilakukan dengan menyebarkan kuisioner kepada pihak perusahaan dan masyarakat yang berpartisipasi dalam program CSR. Data primer diperoleh melalui wawancara mendalam pada responden dan informan. Kuisioner berisikan sejumlah pertanyaan yang berkaitan dengan persepsi, tingkat partisipasi dan dampak yang diperoleh setelah diadakannya kegiatan CSR. Pegumpulan data primer juga dilengkapi dengan wawancara mendalam menggunakan panduan pertanyaan pada informan.

Subyek dalam penelitian ini akan dibedakan menjadi responden dan informan. Responden adalah masyarakat yang berperan dan berpartisipasi terhadap program CSR yang diadakan oleh PT. Bukit Asam (Persero) Tbk. Pemilihan responden dilakukan dengan metode purposive (kesengajaan), yakni dengan menetapkan masyarakat yang telah ikut serta dalam program CSR lebih dari dua tahun. Hal inidilakukan dengan pertimbangan agar responden dapat mempresentasikan kejadian yang ada di lapangan.

Purposive sampling mempunyai suatu tujuan atau dilakukan dengan sengaja. Cara pengambilan sampel dilakukan di antara populasi sehingga sampel tersebut dapat mewakili karakteristik populasi yang telah dikenal sebelumnya (Mardalis, 2004). Dalam menentukan jumlah sampel Roscoe (Roscoe, 1975) menyatakan bahwa untuk penelitian eksperimen yang sederhana, dengan pengendalian yang ketat, ukuran sampel 65end antara 10-20 elemen. Sebagian besar uji 65endidika selalu menyertakan rekomendasi ukuran sampel. Dengan kata lain, uji-uji 65endidika yang ada akan sangat efektif jika diterapkan pada sampel yang jumlahnya 30-60 atau dari 120-250. Namun jika sampelnya di atas 500, tidak direkomendasikan untukmenerapkan uji 65endidika (Champion, 1981).

Jumlah responden yang diambil adalah 236 responden. Sedangkan informan adalah pihak perangkat desa dana kecamatan, serta PT. Bukit Asam (Persero) Tbk sebagai perusahaan yang menjalankan CSR dan juga pihak-pihak lain yang terkait. Jumlah informan tidak dibatasi guna menambah gambaran yang lebih mendalam. Selain itu, tidak menutup kemungkinan responden yang mengisi kuesioner diwawancara untuk mendalami persepsi masyarakat terhadap program CSR yang telah diterima. Sedangkan, data sekunder yang digunakan yaitu gambaran umum perusahaan dari kebijakan CSR yang dilaksanakan perusahaan yang meliputi landasan, kebijakan, pengorganisasian, rencana, serta realisasi CSR.

Wilayah survey nilai manfaat CSR - PKBL PT. Bukit Asam (Persero) Tbk. ini terdiri dari 17 desa/Kelurahan yang berada di tiga kecamatan di Kabupaten Muara Enim, yaitu Kecamatan Tanjung agung yang terdiri dari 2 desa/Kelurahan, Kecamatan Lawang Kidul yang terdiri dari 7 desa/kelurahan, dan Kecamatan Muara Enim yang terdiri dari 8 desa/kelurahan. Terpilihnya 17 desa/kelurahan sebagai wilayah survey nilai manfaat CSR - PKBL PT. Bukit Asam (Persero), Tbk. Dimungkinkan karena berdasarkan kepada analisis dokumen program CSR-PKBL yang dilakukan oleh PT. Bukit Asam (Persero) Tbk, dimana lokasi pelaksanaan program didominasi dilaksanakan di 17 desa/ kelurahan tersebut. 


\section{Hasil dan Pembahasan}

Kategori program peningkatan ekonomi dikaitkan dengan upaya-upaya PT. Bukit Asam (Persero) Tbk untuk meningkatkan ekonomi masyarakat disekitar perusahaan. Dalam hal ini, program yang terkait dengan tujuan ini adalah bentuk program kemitraan, dimana masyarakat di 3 kecamatan, dijadikan mitra usaha oleh PT. Bukit Asam (Persero) Tbk dengan cara pemberian modal usaha.

Sebagian masyarakat Kelurahan Pasar Tanjung Enim menjdi pedagang/ wiraswasta dan buruh tani/ tambang. Hal ini tidak terlepas dengan keberadaan PT. Bukit Asam (Persero) Tbk dan seluruh aktivitas pertambangannya. Kemudian ada pula masyarakat yang berkerja sebagai mitra PT. Bukit Asam (Persero) Tbk dengan adanya Kegiatan Usaha Bersama (KUB). Kegiatan usaha bersama ini dilakukan di berbagai sektor usaha seperti, sektor industri, sektor perdagangan, sektor pertanian, sektor perkebunan, sektor jasa, dan sektor Lainnya.

Program Ekonomi yang telah dilakukan oleh pihak perusahaan yang diketahui oleh masyarakat di 17 desa adalah program CSR berupa (1) Pinjaman Modal untuk Usaha Kecil; (2) Pelatihan pembuatan songket; (3) Pelatihan menjahit; (4) Pembagian Sembako; (5) Pemberian Benih Ikan Lele dan (6) Pembagian dan Pelatihan bibit terong.

Terhadap program-program kemitraan yang disalurkan oleh PT. Bukit Asam (Persero) Tbk kepada warga, dilakukan penilaian manfaat peningkatan ekonomi dengan menggunakan alat ukur berupa bantuan kemitraan. Adapun hasil dari pengukuran nilai manfaat tersebut, didapat data sebagai berikut:

Gambar 2. Nilai Manfaat Peningkatan Ekonomi Tahun 2014-2015

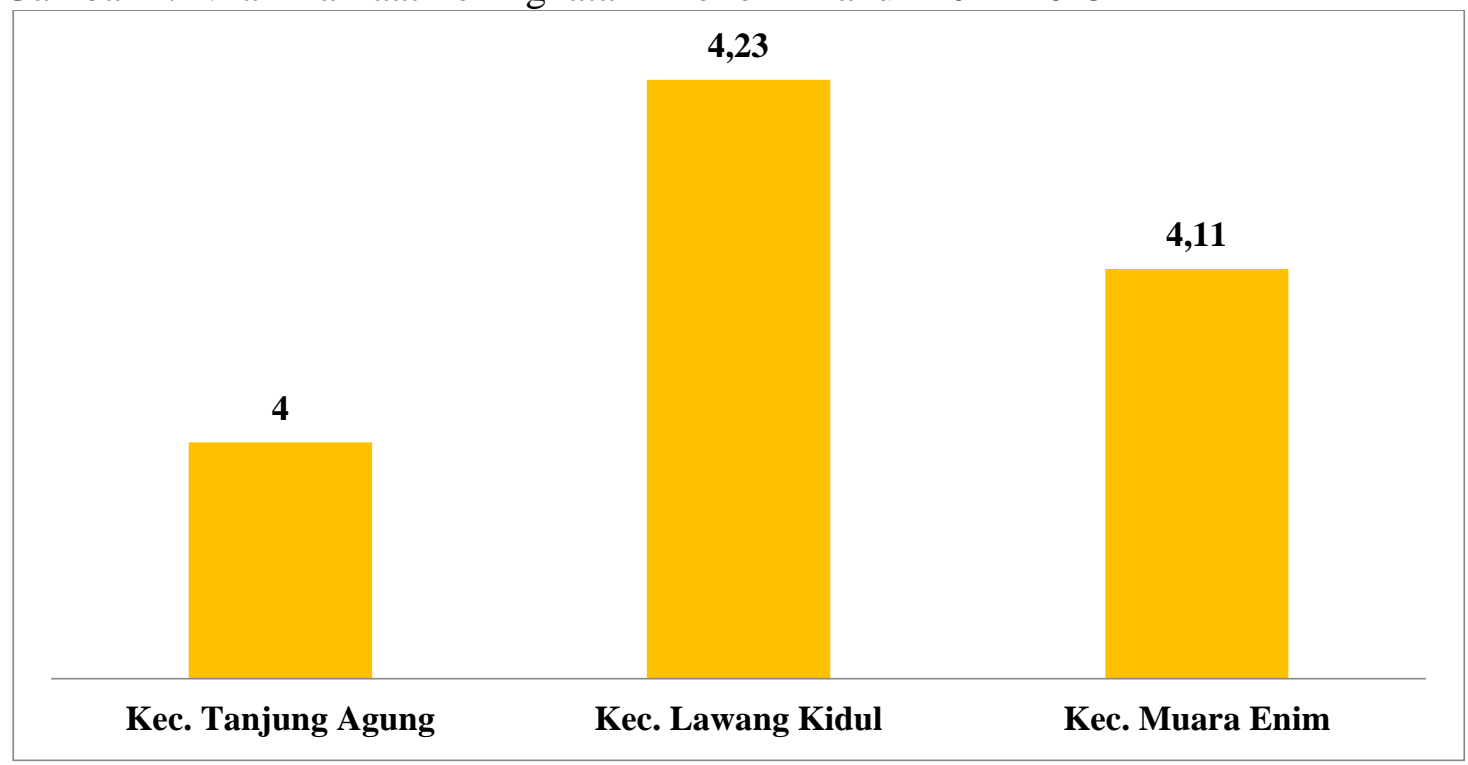

Dari nilai rata-rata pengukuran manfaat program peningkatan ekonomi tersebut didapatkan bahwa masyarakat di 3 kecamatan merasa perekonomiannya meningkat. Hal ini dikarenakan sebagian besar masyarakat merasa bahwa bantuan kemitraan yang 
diberikan oleh PT. Bukit Asam (Persero) Tbk kepada mereka sangat membantu dalam peningkatan perekonomian masyarakatnya.

Kecamatan yang memiliki nilai tertinggi adalah kecamatan Lawang Kidul sebesar 4.23, karena di kecamatan tersebut mendapatkan bantuan kemitraan paling banyak dibandingkan kecamatan lainnya. Seperti halnya di desa keban agung, dengan adanya bantuan kemitraan yang dilakukan oleh PT BA kepada masyarakat di desa tersebut yang awalnya hanya memiliki 2 jenis usaha kini menjadi 12 jenis usaha serta kenaikan jumlah usaha sebesar 14\% (dari 43 usaha ditahun 2013 menjadi 50 usaha ditahun 2016) (hasil wawancara dengan penerima manfaat).

Berdasarkan data dokumen program kemitraan dan wawancara, diketahui terdapat beberapa desa yang belum mendapatkan bantuan kemitraan pada tahun 2014-2015 seperti 2 desa di kecamatan Tanjung Agung yaitu Desa Tanjung Lalang dan Desa Pulau Panggung dimana dari Tahun 2014 sampai 2015 mereka sama sekali belum mendapatkan bantuan kemitraan dari PT. Bukit Asam (Persero) Tbk. Ini menyebabkan persepsi terhadap nilai manfaat peningkatan ekonomi paling rendah di kecamatan Tanjung Agung dibandingkan dua kecamatan lainnya.

Program-program ekonomi yang telah diberikan oleh PT. Bukit Asam (Persero) Tbk kepada warga, dilakukan penilaian manfaat program ekonomi dengan menggunakan dua alat ukur yakni peningkatan pendapatan dan peningkatan kesempatan kerja. Adapun hasil dari pengukuran nilai manfaat tersebut, didapat data sebagai berikut:

Gambar 3. Peningkatan Pendapatan

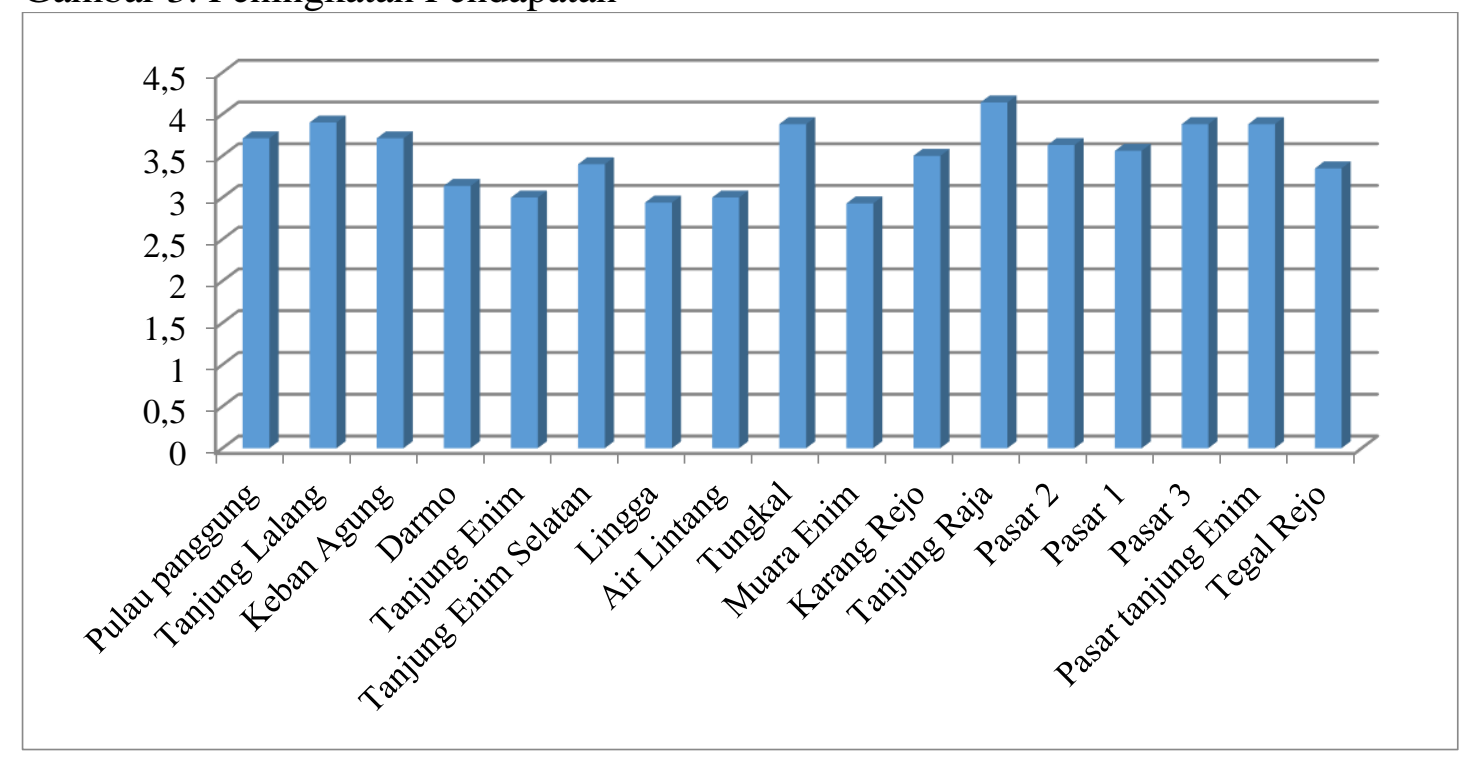

Dari nilai rata-rata untuk program ekonomi didapat nilai tertinggi yaitu pada Desa Tanjung Raja dikarenakan Desa Tanjung Raja paling banyak merespon manfaat program ekonomi PT. Bukit Asam (Persero) Tbk. Adapun program yang didapatkan seperti kerajinan menenun, perikanan dan bantuan modal. Namun secara jumlah bantuan, program peningkatan ekonomi dalam bentuk program kemitraan di Desa Tanjung Raja 
jumlahnya rendah dibandingkan desa lainnya. Berdasarkan observasi dan wawancara terhadap penerima program, dapat disimpulkan bahwa program yang diberikan oleh perusahaan berdampak positif bagi penerima, sehingga persepsi terhadap nilai manfaat peningkatan ekonomi menjadi tinggi di desa ini.

Sedangkan untuk nilai rata-rata sedang berada didesa Tanjung Lalang, Tebat Agung, Tungkal, Pulau Panggung, Karang Rejo, Pasar 1, Pasar 2, Pasar 3, Pasar Tanjung Enim. Hal ini karena sebagian besar desa mendapatkan bantuan program ekonomi namun kebanyakan tidak berhasil seperti ada bantuan bibit lele namun tidak berhasil karena tidak ada pelatihan.

Dan untuk desa dengan nilai rata-rata terendah terdapat pada Desa Tanjung Enim, Tanjung Enim Selatan, Darmo, Air Lintang, Lingga, Muara Enim, Tegal Rejo, Pasar 1, Darmo, Tegal Rejo. Untuk desa Tanjung Enim, Tanjung Enim Selatan, Darmo, Air Lintang memang berdasarkan dokumen program kemitraan tidak mendapatkan program kemitraan di tahun 2014-2015 (lihat 68endi IV.2), sehingga wajar memebrikan nilai persepsi paling rendah dibandingkan desa lainnya. Program yang diketahui oleh masyarakat lebih kepada bentuk-bentuk program langsung seperti program pembagian sembako, sedangkan bentuk program kemitraan tidak diketahui oleh masyarakat didesadesa ini. Namun untuk kelurahan Tanjung Enim tercatat mendapatkan program kemitraan yang cukup banyak, tetapi memberikan persepsi yang rendah dibandingkan desa lainnya.

Adapun peningkatan ekonomi dalam bentuk pendapatan, dilihat dari berapa besar laba yang mampu diperoleh oleh mitra-mitra setelah mendapatkan bantuan modal melalui program kemitraan. Peningkatan laba atau pendapatan tersebut dapat dilihat dari hasil berikut :

Gambar 4. Penilaian Peningkatan Ekonomi Penerima Program Sebelum dan Sesudah Menerima Program

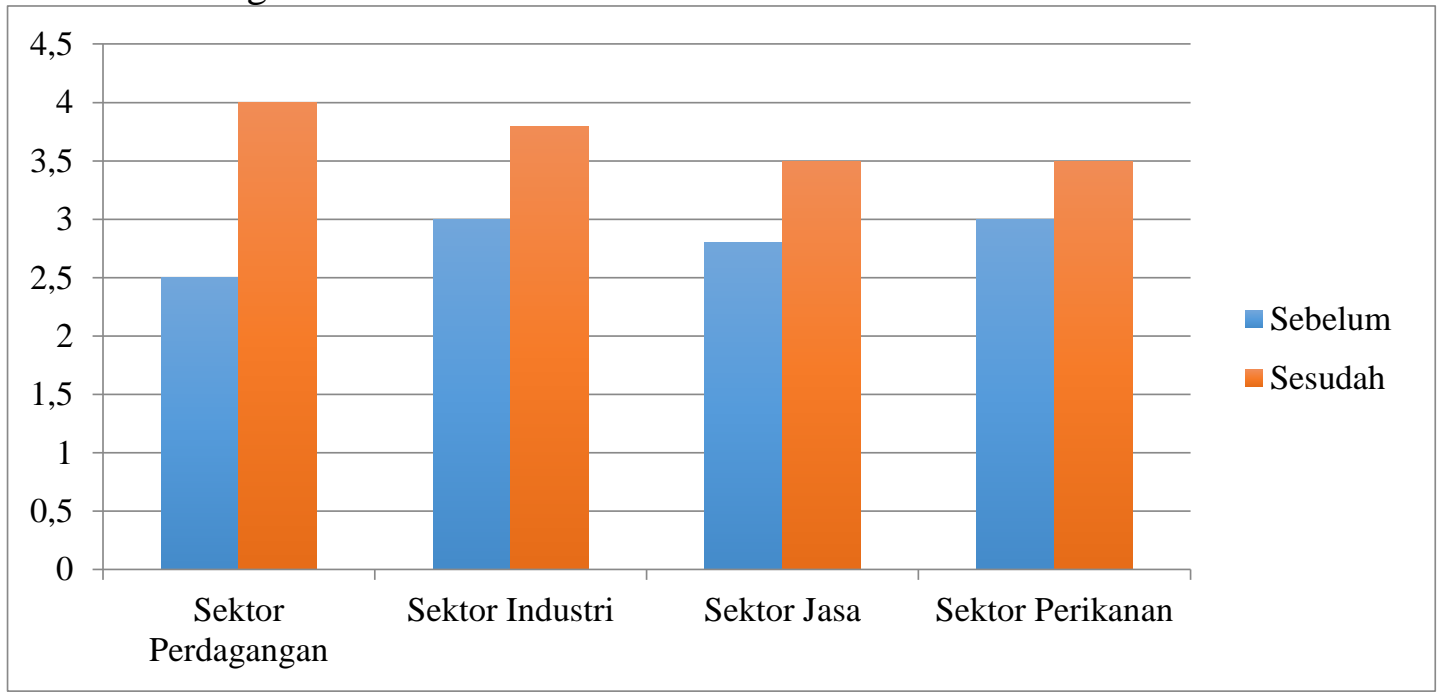

Berdasarkan data diatas, perbandingan yang dilakukan oleh responden terhadap manfaat program, dikaitkan dengan sebelum dan sesudah program adalah seperti yang 
diilustrasikan diatas. Dalam hal ini, responden penerima program kemitraan diminta untuk memberika penilaian terhadap perekonomian mereka sebelum menerima program kemitraan, dan lalu membandingkan perekonomian usaha mereka setelah menerima bantuan program kemitraan. Berdasarkan kategori jenis usaha, maka didapat untuk sektor perdagangan memproleh peningkatan paling tinggi dari 2.5 (rendah) menjadi 4 (tinggi). Sedangkan sektor industri mengalami peningkatan dari 3 (cukup) menjadi 3.8 (tinggi), dan sektor jasa dari 2.8 (rendah) menjadi 3.5 (cukup). Selanjutnya sektor perikanan dari 3 (cukup) menjadi 3.5 (tinggi).

Artinya, sektor perdagangan yang selama ini menjadi sektor dominan dalam pembagian modal kemitraan mempunyai peningkatan paling tinggi diantara sektor lainnya. Namun ini seharusnya tidak menjadikan sektor lain dibatasi untuk dibantu program kemitraan. Bantuan modal kemitraan diiringi dengan bantuan teknis diyakini dapat memberikan nilai manfaat yang tinggi kepada sektor-sektor lain, terutama sektor pertanian yang masih menjadi tulang punggung perekonomian masyarakat kabupaten Muara Enim.

\section{Simpulan}

Jika dibandingkan antara persepsi nilai manfaat dan jumlah bantuan program CSR-PKBL yang digulirkan oleh PT.Bukit Asam (Persero) Tbk terdapat hubungan yang terbalik. Dimana, beberapa desa, terutama desa-desa atau kelurahan yang berdekatan dengan kantor operasi PT.Bukit Asam (Persero) Tbk, yang diprioritaskan oleh perusahaan untuk dibantu dan mendapatkan jumlah bantuan yang tinggi dibandingkan desa lainnya didalam penelitian ini, memberikan persepsi nilai manfaat yang sedang atau rendah dibandingkan desa-desa yang secara relative lebih sedikit menerima bantuan program CSR-PKBL. Ini mengindikasikan bahwa manfaat program CSR-PKBL tidak hanya dapat dilihat dari jumlah atau besaran dana yang telah digulirkan oleh perusahaan kepada masyarakat, namun nilai manfaat sangat dipengaruhi dengan pendekatan dan pengelolaan program, yang dapat melibatkan partisipasi aktif dari seluruh kelompok masyarakat. Artinya, program CSR-PKBL tidak dapat hanya menempatkan masyarakat sebagai objek penerima bantuan, namun program juga harus dapat menempatkan masyarakat sebagai mitra dari program yang digulirkan.

Program CSR-PKBL masih terfokus atau didominasi program-program pembangunan infrastruktur baik 69endidikan, kesehatan maupun sarana umum. Program-program dalam bentuk pemberdayaan ekonomi terutama upaya-upaya untuk peningkatan pendapatan masyarakat seperti pelatihan-pelatihan dan pendampingan masyarakat masih sangat minim dilakukan oleh perusahaan. Hal ini dapat dipahami dikarenakan peraturan yang dibuat dalam Peraturan Bupati Nomor 30 Tahun 2011 hanya mewajibkan perusahaan untuk 69endi kepada pembangunan sarana dan prasarana baik dalam 69endidikan, kesehatan maupun umum.

Perusahaan untuk lebih memprioritaskan pengalokasian program kepada masyarakat yang betul-betul terkena dampak dan juga minim akses baik secara ekonomi, 69endidikan, kesehatan serta program pembangunan lainnya. Survey mengindikasikan bahwa program-program CSR-PKBL PT.Bukit Asam (Persero) Tbk, walaupun bernilai kecil dibandingkan dengan desa-desa lainnya, namun lebih diapresiasi nilai manfaatnya oleh masyarakat didesa-desa yang dikategorikan minim dalam akses-akses tersebut. 
Sebaliknya, program CSR-PKBL yang selama ini diprioritaskan kepada desa/ kelurahan terdekat dengan kantor PT.Bukit Asam (Persero) Tbk justru memberikan persepsi nilai manfaat yang sedang dan bahkan rendah terhadap program-program CSR-PKBL yang telah digulirkan oleh perusahaan. Hasil ini menunjukkan bahwa program CSR-PKBL perusahaan akan lebih bermanfaat bagi desa-desa dalam kategori minim akses tersebut. Pengkategorian desa-desa berdasarkan lokasi kedekatan dengan perusahaan atau yang termasuk ring 1, seharusnya mulai diganti dengan desa-desa yang terkena dampak dan minim akses ini.

Meningkatkan program-program CSR-PKBL dalam bentuk pemberdayaan masyarakat baik itu berupa pelatihan maupun pendampingan. Hingga saat ini, perusahaan telah berkomitmen untuk menunaikan kewajiban untuk peningkatan ekonomi masyarakat melalui program kemitraan. Namun penyediaan bantuan keuangan di program kemitraan perlu dibarengi dengan bantuan teknis seperti pelatihan dan pendampingan untuk memastikan bahwa bantuan program kemitraan bermanfaat optimal bagi masyarakat. Berdasarkan wawancara dengan masyarakat diketahui bahwa banyak program-program bantuan seperti pemberian bibit ataupun pengembangan pertanian tidak berjalan dengan semestinya dikarenakan program tidak mendampingi bantuan dengan program-program pelatihan dan pembinaan yang intens terhadap masyarakat.

\section{Daftar Pustaka}

Ambadar, J. (2008). CSR dalam Praktik di Indonesia. Elex Media Computindo.

Anatan, L. (2010). Coorporate Social Responsibility (CSR): Tinjauan teoritis dan praktik di Indonesia. Jurnal Manajemen, 8, pp-66.

Carroll, A.B., \& Buchholtz, A.K. (2014). Business and Society: Ethics, Sustainability, and Stakeholder Management. Nelson Education.

Champion, D.J. (1981). Basic Statistics For Social Research. Macmillan College.

Elkington, J. (2004). Enter the triple bottom line. The triple bottom line: Does it all add up. Routledge.

Gyves, S., \& O'Higgins, E. (2008). Corporate social responsibility: An avenue for sustainable benefit for society and the firm? Society and Business Review, 3, pp. 207223.

Irwanto, A.K., \& Prabowo, A. (2009). Kajian efektivitas program corporate social responsibility (CSR) Yayasan Unilever Indonesia. Jurnal Manajemen, 1.

Lenssen, G., Bevan, D., Fontrodona, J., \& Drews, M. (2010). Measuring the business and societal benefits of corporate responsibility. Corporate Governance: The International Journal of Business in Society, 10, pp. 421-431.

Mardalis. (2004). Metode Penelitian. Bumi Aksara.

Roscoe, J. (1975). Fundamental Research Statistics for the Behavioural Science, 2nd Ed. Holt Rinehart \& Winston, New York.

Van Marrewijk, M. (2003). Concepts and definitions of CSR and corporate sustainability: Between agency and communion. Journal of business ethics, 44, pp. 95-105.

Waagstein, P.R. (2011). The mandatory corporate social responsibility in Indonesia: Problems and implications. Journal of Business Ethics, 98, pp. 455-466.

Zainal, R. (2015). Mandated Corporate Social Responsibility (CSR) in Indonesia: Institutional and stakeholder perspectives (Disertasi yang dipublikasikan). RMIT, Australia. Diunduh dari: https://researchbank.rmit.edu.au/view/rmit:161737 
MBIA

p-ISSN 2086-5090, e-ISSN: 2655-8262

Vol. 17, No. 3, 2018

\section{Copyright Disclaimer}

Copyright for this article is retained by the author(s), with first publication rights granted to the journal. 